\title{
Resveratrol Modulates Expression of ABC Transporters in Non-Small Lung Cancer Cells: Molecular Docking and Gene Expression Studies
}

\section{Subburayan Karthikeyan ${ }^{1,2 *}$, Sugeerappa Laxmanappa Hoti ${ }^{1}$ and Nagarajan Rajendra Prasad ${ }^{2}$}

${ }^{1}$ Regional Medical Research Centre (ICMR), Department of Health Research, Nehru Nagar- 590010, Belgaum, Karnataka, India ${ }^{2}$ Department of Biochemistry and Biotechnology, Annamalai University, Annamalainagar-608 002, Tamilnadu, India

\begin{abstract}
Multidrug resistance is one of the most common causes of relapse in cancer chemotherapy. Inhibition of ABC transporters to reverse MDR is a prominent approach to enhance the efficacy of cancer chemotherapy. We investigated the effect of resveratrol (RSV) on the membrane transport function and the expression of proteins involved in the multidrug resistance in $\mathrm{NCl}-\mathrm{H} 460 \mathrm{cells}$. The molecular interactions of RSV with P-gp were analyzed by Schrodinger software. The membrane transport function and cell cycle distribution were measured using flow cytometry. The mRNA expression level of MDR1, LRP, MRP2, ABCC1, ABCC2 and ABCC3 genes were detected by qRT-PCR and BCRP expression was detected by western blot analysis. In silico docking studies revealed that RSV possesses greater binding affinity with TMD region of P-gp. In this study, RSV pretreatment significantly enhanced Paclitaxel (PTX) antiproliferative effect in NCl-H460 cells. The rhodamine 123 drug efflux studies revealed that there was a significant transport function inhibition by RSV treatment and moderate transport function inhibition by PTX. Further, RSV treatment significantly decreased the mRNA expression levels of various ABC transporters genes. Furthermore, expression of BCRP was found to be down-regulated during RSV treatment. It was also found that this enhanced anticancer efficacy of RSV was associated with PTX-induced cell arrest in the G2/M phase of cell cycle. Interestingly, we observed significantly enhanced antiproliferative effect, transport function inhibition and downregulation of ABC transporters in RSV-PTX combination group. This might be due to additive or synergistic effect of RSV with PTX in $\mathrm{NCl}-\mathrm{H} 460$ cells. Thus, the present findings illustrate the modulatory role of RSV on PTX sensitization in relatively resistant $\mathrm{NCl}-\mathrm{H} 460$ cells.
\end{abstract}

Keywords: Multidrug resistance; Resveratrol; Paclitaxel; Docking; Rhodamine 123

Abbreviations: ABC: ATP Binding Cassettes; MDR: Multi Drug Resistance; P-gp: Phospho Glycoprotein; MRP1: Multidrug Resistance Associated Protein 1; LRP: Lung Cancer Resistance Protein; BCRP: Breast Cancer Resistance Protein; PDB: Protein Data Bank

\section{Introduction}

Lung cancer is the leading cause of cancer-related deaths throughout the world, with a higher annual death rate than prostate, colon and breast cancers combined and a dismal 5-year survival rate of $15 \%$ [1]. Non-small cell lung cancer (NSCLC) comprises approximately $75-80 \%$ of all lung cancers. It is well known that MDR is a major obstacle in the chemotherapy of NSCLC. It has been reported that several $\mathrm{ABC}$ transporters are involved in resistance to known anticancer drugs such as doxorubicin, paclitaxel, vincristine and etoposide [2]. A number of reports have shown that MDR results due to over expression of ATP-binding cassette (ABC) transporters, such as $\mathrm{P}$-gp (ABCB1/P-gp), multidrug resistance associated proteins (ABCC1, 2 and 3/MRPs) and breast cancer resistant protein (ABCG2/ $\mathrm{BCRP}$ ). These $\mathrm{ABC}$ transporters promote the active efflux of the structurally and functionally diverse amphipathic anticancer drugs from cancer cells, which can result in chemoresistance [3]. Clinically, several resistance proteins, including P-gp, lung resistance protein (LRP) and MDR associated protein, are proved to be simultaneously involved in MDR of NSCLC [4,5]. High expression level of LRP was detected at the nuclear envelope and cytoplasm in lung cancer cells [6].

The inhibition of $\mathrm{ABC}$ transporters to reverse MDR in cancer cells might be a prominent approach to enhance the efficacy of cancer chemotherapy. A number of modulators have been identified for the down-regulation MDR related proteins. However, currently available MDR modulators non-selectively inhibit $\mathrm{ABC}$ transporters and adversely accumulate chemotherapeutic drugs in brain and kidney [7]. Utilizing natural products for the development of next generation $\mathrm{ABC}$ modulators, especially after the disappointing results obtained from the first three generation $\mathrm{ABC}$ modulators at the clinical trial stage, gains much more importance [8]. Systematic high-throughput screening of traditional natural products will be the first step in the discovery of nontoxic, potent and selective inhibitors. Many phenolic and flavonoids are excellent modulators of major ABC drug transporters [9-12]. Flavonoids can change the overall pharmacokinetics, including drug absorption, penetration and elimination by modulating the functions of $\mathrm{ABC}$ transporters $[13,14]$. Flavonoids are also reported to modulate (rather than inhibit) the function of $\mathrm{ABC}$ transporters, depending on the substrate of interest [15]. Resveratrol (RSV) trans-3,5,4trihydroxystilbene, a phytoalexin, from the skin and seeds of grapes and a component of red wine, has been reported to possess antioxidant [16], antiinflammatory $[17,18]$ and cancer chemopreventive [1921] properties. Reports show that RSV can mediate the activities of many important signaling molecules involved in cancer cell death and survival, such as NF-kB [22], activator protein-1 (AP-1), Akt, tumor suppressor gene $\mathrm{p} 53$, growth factors signaling, chemokines and metatasis, tumor necrosis factor (TNF), signal transducer and activator of transcription, cyclooxygenase-2 (COX-2), inducible nitric oxide synthase (iNOS), mitogen-activated protein (MAP) kinases, and angiogenesis $[23,24]$. Furthermore, RSV increases sensitivity of mice hepatoma cells to 5 -flurouracil action. Moreover, RSV has been found to sensitize 5-FU effects on tumor xenograft in vivo [25]. Additionally,

*Corresponding author: Karthikeyan S, Regional Medical Research Centre (ICMR), Nehru Nagar, Belgaum-590 010, Karnataka State, India, Tel: 08312475477; Fax: 0831-2475479; E-mail: akashkarthik85@gmail.com

Received October 29, 2014; Accepted December 29, 2014; Published December 31,2014

Citation: Karthikeyan S, Hoti SL, Prasad NR (2014) Resveratrol Modulates Expression of ABC Transporters in Non-Small Lung Cancer Cells: Molecular Docking and Gene Expression Studies. J Cancer Sci Ther 6: 497-504. doi:10.4172/1948-5956.1000314

Copyright: (c) 2014 Karthikeyan S, et al. This is an open-access article distributed under the terms of the Creative Commons Attribution License, which permits unrestricted use, distribution, and reproduction in any medium, provided the original author and source are credited. 
RSV mediates reversal of doxorubicin resistance in acute myeloid leukemia cells via downregulation of MRP1 expression [26]. Paclitaxel (PTX), a known anticancer drug, works by interfering with normal microtubule breakdown during cell division. PTX has been considered one of the most successful anticancer drugs and has shown potency against a broad spectrum of cancers [27,28]. However, lung cancer shows significant resistance to PTX treatment [29]. As RSV increases the efficacy of anticancer drugs in several experimental models $[25,26]$, in the present study, we investigated the modulatory role of RSV on PTX sensitization in resistant human non small cell lung cancer (NCI-H460) cells in vitro.

\section{Materials and Methods}

\section{Chemicals}

Resveratrol, Paclitaxel, 3-(4,5-dimethylthiazol-2-yl)-2,5-diphenyl tetrazolium bromide (MTT), Rhodamine 123 (Rh-123), Heat inactivated fetal calf serum (FCS), RPMI-1640 medium, Glutaminepenicillin-streptomycin solution, Trypsin-EDTA, qRT-PCR primers, Monoclonal antibodies for BCRP, anti- $\beta$-actin antibody mouse and goat anti-mouse IgG-HRP polyclonal antibody were purchased from Sigma Chemicals Co., St. Louis, USA. Analytical grade acetone, ethanol, dimethyl sulfoxide (DMSO) were bought from SRL, India.

\section{Molecular docking studies}

The 3D structure of the P-gp was downloaded from Protein Data Bank (PDB) and modified. The modification included removal of water molecules from the cavity, stabilizing charges, filling in the missing residues, generation of side chains etc, according to the parameters available. After modification the transporter was biologically active and stable. Using chemdraw software the structure of the drugs and analogs were sketched drawn and generated their MOL structure. RSV was docked at each of the generated grids (sites 1 to 4 and the ATP binding site of P-gp by using the "Extra Precision" (XP) mode of Glide program v5.0 (Schrçdinger, Inc., New York, NY, 2009) with the default functions. The top scoring ligand's conformation was used for graphical analysis. All computations were carried out on a Dell Precision 470n dual processor with Linux OS (Red Hat Enterprise WS 4.0).

\section{Cell lines, culture conditions and experimental groups}

The present work was carried out in NCI-H460 cell line. NCI-H460 cells were obtained from National Centre for Cell Science (NCCS), Pune, India. Cells were cultured as monolayers in RPMI-1640 medium, supplemented with $10 \%$ fetal bovine serum (FBS), penicillin and streptomycin in a humidified atmosphere of $95 \%$ air and $5 \% \mathrm{CO}_{2}$ at $37^{\circ} \mathrm{C}$. They were grown to exponential growth phase and treated with different concentration of PTX $(0-10 \mu \mathrm{g} / \mathrm{mL})$ and RSV $(0-20 \mu \mathrm{g} /$ $\mathrm{mL}$ ). Cytotoxicity was observed after $24 \mathrm{~h}$ incubation by MTT assay according to the method of Moshmann [30]. $\mathrm{IC}_{50}$ values of the drug were determined and the optimum dose was used for further study. The NCI-H460 cells were divided into 4 experimental groups. Group 1: Untreated control cells, Group 2: RSV alone $(10 \mu \mathrm{g} / \mathrm{mL})$ treated, Group 3: PTX alone $(5 \mu \mathrm{g} / \mathrm{mL})$ treated, Group 4: RSV $(10 \mu \mathrm{g} / \mathrm{mL})$ treatment 1 $\mathrm{h}$ before PTX $(5 \mu \mathrm{g} / \mathrm{mL})$ exposure.

\section{Cell viability assay}

NCI-H460 cells were incubated with RSV and/or PTX for $24 \mathrm{~h}$ at $37^{\circ} \mathrm{C}$, at the end of the incubation period, MTT solution was added to each well and allowed to develop color for additional $4 \mathrm{~h}$. The cell suspension was centrifuged and formazan crystals were dissolved in an equal volume of DMSO to solubilize the formazan crystals. Absorbance was measured in a microplate reader at $540 \mathrm{~nm}$.

\section{Measurement of drug accumulation}

The accumulation of PTX was determined by rhodamine 123 , a fluorescent substrate of P-gp, in cancer cells as has been previously described [31]. Briefly, cells $\left(5 \times 10^{5}\right.$ per sample) were treated with RSV, PTX and RSV-PTX for $60 \mathrm{~min}$ and then incubated with $20 \mu \mathrm{M}$ rhodamine 123 for $1 \mathrm{~h}$ (in the dark, $37^{\circ} \mathrm{C}$ in a $5 \% \mathrm{CO}_{2}$ ). Following rhodamine 123 accumulation, cells were washed twice with ice-cold PBS. Fluorescence intensity of rhodamine 123 in individual cells was measured immediately by a FACScalibur excitation at $488 \mathrm{~nm}$ and emission at $530 \pm 15 \mathrm{~nm}$ (BD Biosciences, San Jose, CA).

\section{Western blot analysis}

NCI-H460 cells were cultured in $60 \mathrm{~mm}$ dishes at $60 \%$ confluency and treated with RSV-PTX with desired concentration. Whole cell proteins were extracted with RIPA lysis buffer $(150 \mathrm{mM} \mathrm{NaCl}, 0.5 \%$ Triton X-100, 50 mM Tris-HCl, pH 7.4, 25 mM NaF, 20 mM EGTA, 1 mM DTT, 1 mM Na3VO4, 0.1\% SDS, and protease inhibitors cocktail) for $30 \mathrm{~min}$ on ice followed by centrifugation at $12,000 \mathrm{rpm}$ for $15 \mathrm{~min}$. The protein concentration of the supernatant was measured by using the BCA reagent. Proteins $(30-40 \mu \mathrm{g})$ were electrophoresed on $12 \%$ gradient Tris-HCl gel (Bio-Rad, semi-dry, USA) and electrotransferred onto polyvinylidene difluoride (PVDF) membrane in Tris-glycine buffer ( $\mathrm{pH}$ 8.4) containing 20\% methanol. The membrane was then blocked in $5 \%$ fat-free dry milk in phosphate-buffered saline with $0.1 \%$ Tween-20 (PBS-T) for $1 \mathrm{~h}$. Membranes were probed with monoclonal anti-BCRP antibody and horseradish peroxidase-conjugated secondary antibody by standard western blot procedures. Then, the membranes were washed with TBST thrice for $10 \mathrm{~min}$, after extensive washes in TBST; the bands were visualized by treating the membranes with 3 , 3'-diaminobenzidine tetrahydrochloride (Western blot detection reagent). Densitometry was done using 'Image J' analysis software.

\section{mRNA studies of the $\mathrm{ABC}$ transporters}

The total RNA was extracted from the NCI-H460 cells using RNeasy Mini kit (Qiagen, USA) as per the protocol recommended by the manufacturer. The mRNA expression of $A B C B 1 / M D R 1$, MDR3, LRP, ABCC1, ABCC2 and ABCC3 in NCI-H460 cells was determined using real-time PCR (Eppendorff, Thermocycler, USA) and the primer sequences are given in Table 1. Samples were run in triplicate to ensure amplification integrity. Manufacturer-supplied (Sigma Aldrich, Bangalure, India) primer pairs were used to measure the mRNA expression. For cDNA synthesis, PCR cyclic condition used were $25^{\circ} \mathrm{C}$ for $10 \mathrm{~min} ; 42^{\circ} \mathrm{C}$ for $50 \mathrm{~min} ; 75^{\circ} \mathrm{C}$ for $15 \mathrm{~min}$. The cyclic condition used for cDNA amplification was $95^{\circ} \mathrm{C}$ for $2 \mathrm{sec} ; 55^{\circ} \mathrm{C}$ for $15 \mathrm{sec}$; and $68^{\circ} \mathrm{C}$ for $20 \mathrm{sec}$, as recommended by the manufacturer. The expression levels of genes were normalized to the expression level of the $18 \mathrm{~S}$ mRNA in each sample. The threshold for positivity of realtime PCR was determined based on negative controls. The calculations for determining the relative level of gene expression were made using the cycle threshold $(\mathrm{Ct})$ method. The mean $\mathrm{Ct}$ values from triplicate measurements were used to calculate the expression of the target gene using the $2^{-\Delta \Delta \mathrm{Ct}}$ formula.

\section{Cell cycle analysis}

NCI-H460 cells $\left(3.5 \times 10^{6}\right)$ seeded on the 6-well plates were treated with RSV, PTX and their combination group at $37^{\circ} \mathrm{C}$ for $24 \mathrm{~h}$. For analyzing DNA content, $2 \times 10^{6}$ cells were fixed in $90 \%$ ethanol in PBS 
Citation: Karthikeyan S, Hoti SL, Prasad NR (2014) Resveratrol Modulates Expression of ABC Transporters in Non-Small Lung Cancer Cells: Molecular Docking and Gene Expression Studies. J Cancer Sci Ther 6: 497-504. doi:10.4172/1948-5956.1000314

\begin{tabular}{|c|c|}
\hline Gene name & Primer sequence \\
\hline MDR1 & $\begin{array}{l}\text { F: 5' TGGAGGTAAGTGACCCAGGGCTG 3' } \\
\text { R: 5' AGGCAATCCGATGCAGAGCCCA 3' }\end{array}$ \\
\hline MDR3 & $\begin{array}{l}\text { F: 5' TCCCACCCGAGCAAACGTGC 3' } \\
\text { R: 5' CCCCGCCAAGGGGTCGTAGA 3' }\end{array}$ \\
\hline$L R P 1$ & $\begin{array}{l}\text { F: 5' CAATGCACGGAGGCAGCCCA 3' } \\
\text { R: 5' GCCCCCATTGCGACAGTGCT 3' }\end{array}$ \\
\hline$A B C C 1$ & $\begin{array}{l}\text { F: 5' GTGGCTATCAAGGGCTCCGTGG 3' } \\
\text { R: 5' TCCGCGTCTTCTCGCCAATCT 3' }\end{array}$ \\
\hline$A B C C 2$ & $\begin{array}{l}\text { F: 5' GTCTTCGTTCCAGACGCAGTCC 3' } \\
\text { R: 5' CACGTGGAGAAGCTGCCAGGG 3' }\end{array}$ \\
\hline$A B C C 3$ & $\begin{array}{l}\text { F: 5'GGCATGGCCAGGGCTCATTGG 3' } \\
\text { R: 5' GGTCCACGTACACGTACACCCA 3' }\end{array}$ \\
\hline $18 S$ rRNA & $\begin{array}{l}\text { F: 5' AGGAATTCCCAGTAAGTGCG 3' } \\
\text { R: 5' GCCTCACTAAACCATCCAA 3' }\end{array}$ \\
\hline
\end{tabular}

Table 1: List of various $A B C$ transporters primer sequence.

at $4{ }^{\circ} \mathrm{C}$. After $12 \mathrm{~h}$, the fixed cells were pelleted, gently resuspended in ice cold PBS and stained with $0.5 \mathrm{mg} / \mathrm{mL}$ Propidium iodide plus $50 \mu \mathrm{g} / \mathrm{mL}$ RNAase. The samples were then incubated at $37^{\circ} \mathrm{C}$ for 30 min, stored in the dark at $4^{\circ} \mathrm{C}$. The red fluorescence of the individual cells was measured at an excitation wavelength of $540 \mathrm{~nm}$ and an emission wavelength at $610 \mathrm{~nm}$ in a FACScaliber flow cytometer (BD Biosciences, San Jose, CA). A minimum of 10,000 events were analyzed per each samples using CellQuest software.

\section{Statistical analysis}

Data are expressed as means \pm standard error of the mean (SE). Statistical differences were determined by one-way analysis of variance (ANOVA). P values less than 0.05 were considered significant.

\section{Results}

\section{In silico molecular interaction of RSV with TMD region of} P-gp

In the work presented here, we explored the binding affinity (in terms of the docking energy in $\mathrm{kcal} / \mathrm{mol}$, docking score and hydrogen bond score) of RSV, a polyphenol towards P-gp target. The molecular interaction of RSV (PubChem CID: 445154) with P-gp (PDB ID: 3G61) were analyzed by Schrodinger software (Figure 1a-d). The results were analyzed at the best orientation of the ligand RSV with P-gp and the docking images were documented for representation of ligand-receptor interaction. Table 2 shows the values of docking score (-8.343297), glide score (-8.3433) and hydrogen bond score (-1.21375) which indicate that RSV possessed a significant binding affinity with P-gp. It has also been found that RSV forms hydrogen bonding with $\mathrm{Tyr}^{113}$ and $\mathrm{Tyr}^{949}$ residues which are located within the helical TMD region of P-gp shown in UniPort Database (UniPort ID: P21447).

\section{Dose fixation study}

Selection of optimum RSV and PTX concentration for the study: The antiproliferative effect of RSV was found to be concentration dependent and $100 \%$ cell death was observed at $20 \mu \mathrm{g} / \mathrm{mL}$ in NCI-H460 cells (Table $3 \mathrm{a}$ ). Table $3 \mathrm{~b}$ showed the percentage cytotoxicity of PTX on NCI-H460 cells. About $100 \%$ cell death was observed at $10 \mu \mathrm{g} / \mathrm{mL}$ concentration of PTX. Based on these findings $10 \mu \mathrm{g} / \mathrm{mL}$ of RSV and $5 \mu \mathrm{g} / \mathrm{mL}$ of PTX (the $\mathrm{IC}_{50}$ values) were chosen for chemosensitizing experiments.
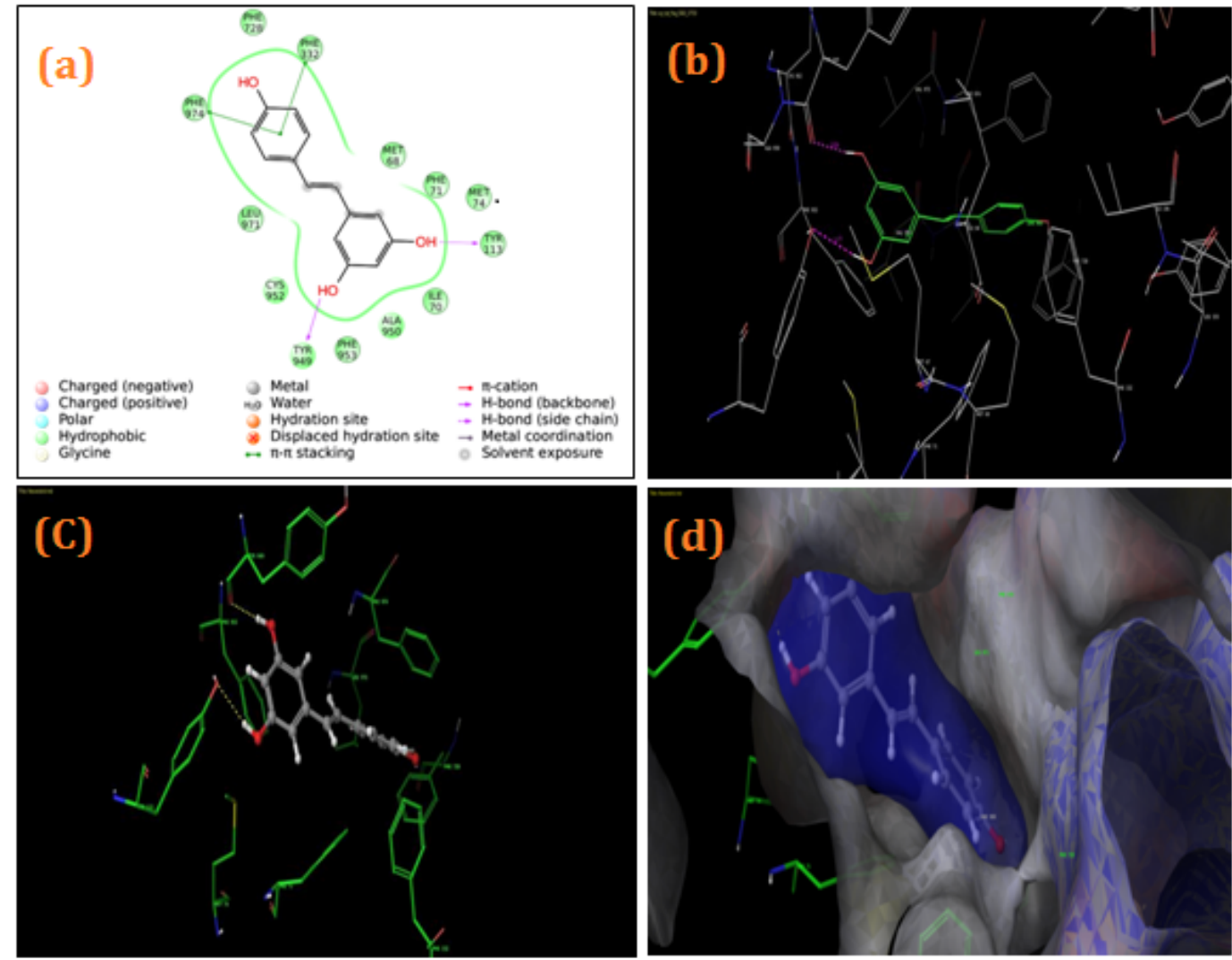

Figure 1: Predicted bonded interactions (pink and yellow dashed lines) between RSV and TMD region of P-gp (a) (b) and (c) 2D and (d) 3D structure. 
Citation: Karthikeyan S, Hoti SL, Prasad NR (2014) Resveratrol Modulates Expression of ABC Transporters in Non-Small Lung Cancer Cells: Molecular Docking and Gene Expression Studies. J Cancer Sci Ther 6: 497-504. doi:10.4172/1948-5956.1000314

\begin{tabular}{|c|c|c|c|c|}
\hline RSV Structure & $\begin{array}{c}\text { Amino acid } \\
\text { residues of TMD } \\
\text { interacting with } \\
\text { RSV }\end{array}$ & $\begin{array}{l}\text { Docking } \\
\text { score }\end{array}$ & $\begin{array}{c}\text { Glide } \\
\text { score }\end{array}$ & $\begin{array}{c}\text { Hydrogen } \\
\text { bond } \\
\text { score }\end{array}$ \\
\hline
\end{tabular}

Table 2: Molecular interaction of RSV (Pubchem CID: 445154) with TMD region of P-gp (PDB ID: 3G61).

\begin{tabular}{|c|c|}
\hline RSV Conc. $(\boldsymbol{\mu g} / \mathbf{m L})$ & Percentage of cytotoxicity \\
\hline 0 & $5.02 \pm 0.2^{\mathrm{a}}$ \\
\hline 5 & $32.12 \pm 1.9^{\mathrm{b}}$ \\
\hline $\mathbf{1 0}$ & $\mathbf{5 3 . 2 4} \pm \mathbf{2 . 6 ^ { \mathrm { c } }}$ \\
\hline 15 & $78.56 \pm 3.2^{\mathrm{d}}$ \\
\hline 20 & $99.75 \pm 3.4^{\mathrm{e}}$ \\
\hline
\end{tabular}

Table 3a: Cytotoxicity of RSV on relatively resistant $\mathrm{NCl}-\mathrm{H} 460$ cells (Dose fixation study). RSV was incubated with cells for $24 \mathrm{~h}$ and $\%$ cytotoxicity was observed by MTT assay. Cell death was observed in a concentration $(0-20 \mu \mathrm{g} / \mathrm{mL})$ dependent manner in $\mathrm{NCl}-\mathrm{H} 460$ cells. $10 \mu \mathrm{g} / \mathrm{mL}$ RSV showed $50 \%$ cell death $\left(\mathrm{IC}_{50}\right)$ in $\mathrm{NCl}-\mathrm{H} 460$ cells.

\begin{tabular}{|c|c|}
\hline PTX Conc. $(\boldsymbol{\mu g} / \mathbf{m L})$ & Percentage of cytotoxicity \\
\hline 0 & $2.12 \pm 0.1^{\mathrm{a}}$ \\
\hline 0.5 & $18.10 \pm 1.2^{\mathrm{b}}$ \\
\hline 1 & $25.42 \pm 1.8^{\mathrm{c}}$ \\
\hline 2.5 & $32.53 \pm 2.0^{\mathrm{d}}$ \\
\hline $\mathbf{5}$ & $\mathbf{4 9 . 5 8} \pm 2.5^{\mathrm{e}}$ \\
\hline 10 & $72.32 \pm 3.1^{\mathrm{f}}$ \\
\hline 10 & $98.91 \pm 3.3^{\mathrm{g}}$ \\
\hline
\end{tabular}

Table 3b: Cytotoxicity of PTX on NCl-H460 cells (Dose fixation study). PTX was incubated with cells for $24 \mathrm{~h}$ and $\%$ cytotoxicity was observed by MTT assay. Cell death was observed in a concentration $(0-10 \mu \mathrm{g} / \mathrm{mL})$ dependent manner in NCl-H460 cells $5 \mu \mathrm{g} / \mathrm{mL}$ PTX showed $50 \%$ cell death $\left(\mathrm{IC}_{50}\right)$ in $\mathrm{NCl}-\mathrm{H} 460$ cells. IC $\mathrm{IC}_{50}$ values are indicated as the mean \pm S.D. of three independent experiments performed. (S.D= standard deviation).

\section{Effect of RSV, PTX and RSV-PTX on cell proliferation in NCI-H460 cells}

NCI-H460 cells were treated with RSV $(10 \mu \mathrm{g} / \mathrm{mL}) 1 \mathrm{~h}$ before PTX $(5 \mu \mathrm{g} / \mathrm{mL})$ exposure and incubated for $24 \mathrm{~h}$. Figure 2 a shows photomicrographs of MTT reduction capability of RSV and RSV-PTX in NCI-H460 cells. Purple colored crystal formation was observed to be more in control group compared with RSV, PTX and RSV-PTX treated groups. Figure $2 \mathrm{~b}$ shows the effect of RSV, PTX and RSV-PTX on percentage cell viability. It was found that RSV alone treatment showed $54 \%$ cell viability and PTX alone treatment showed $50 \%$ cell viability in NCI-H460 cells. The combination of RSV-PTX treatment showed only $10 \%$ cell viability.

\section{Effect of RSV-PTX on accumulation of rhodamine 123 in NCI-H460 cells}

Figure 3 shows the accumulation of rhodamine 123 in NCI-H460 cells. Control cells showed diminished accumulation of rhodamine 123 whereas RSV treated cells showed significantly enhanced rhodamine 123 accumulations. PTX alone treated cells also showed minimum accumulation of rhodamine 123 in NCI-H460 cells when compared to control cells. Thus, the RSV-PTX combination treatment has shown rhodamine 123 accumulation was increased 2.1-fold compared to 7.8fold at PTX alone treatments in NCI-H460 cells.

\section{BCRP protein expression in NCI-H460 cells}

Figure $4 \mathrm{a}$ and $\mathrm{b}$ show the effect of RSV and PTX on the expression pattern of BCRP in NCI-H460 cells. Treatment with RSV alone or PTX alone resulted in 6.2-fold and 3.4-fold decrease in the expression level of BCRP protein in NCI-H460 cells. BCRP protein levels in RSV-PTX treated group was reduced 1.8-fold compared with PTX alone treated cells.

\section{Effect of RSV-PTX on ABC transporters mRNA expression pattern in NCI-H460 cells}

Figure 5 shows the effect of RSV and PTX on the relative mRNA (a)
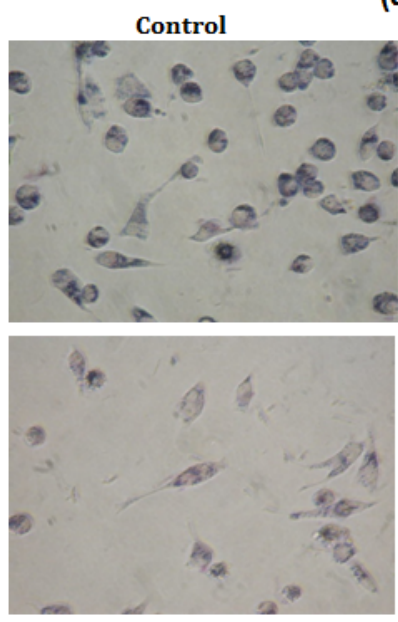

$\operatorname{PTX}(5 \mu \mathrm{g} / \mathrm{mL})$ (a)

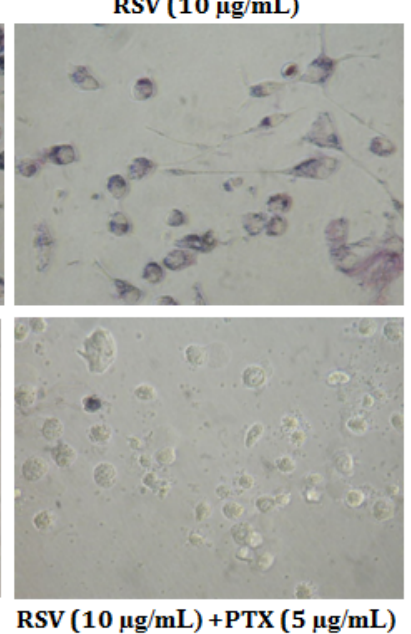

(b)

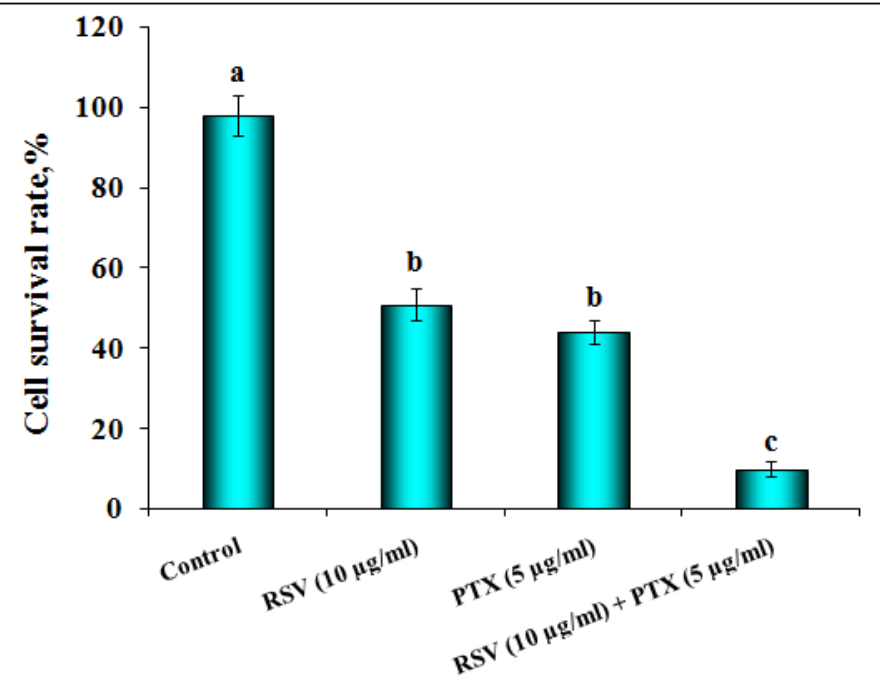

Figure 2: Microscopic images show MTT reduction capability of $\mathrm{NCl}-\mathrm{H} 460$ cells. (a) Microscopic images show the purple colored crystal formation, which is an indication of cell viability. (b) Effect of RSV and PTX on NCl-H460 cells viability. Values are given as means \pm S.D. of six experiments in each group. Values not sharing a common marking (a, b, c) differ significantly at $P \leq 0.05$ (DMRT). 
Citation: Karthikeyan S, Hoti SL, Prasad NR (2014) Resveratrol Modulates Expression of ABC Transporters in Non-Small Lung Cancer Cells: Molecular Docking and Gene Expression Studies. J Cancer Sci Ther 6: 497-504. doi:10.4172/1948-5956.1000314

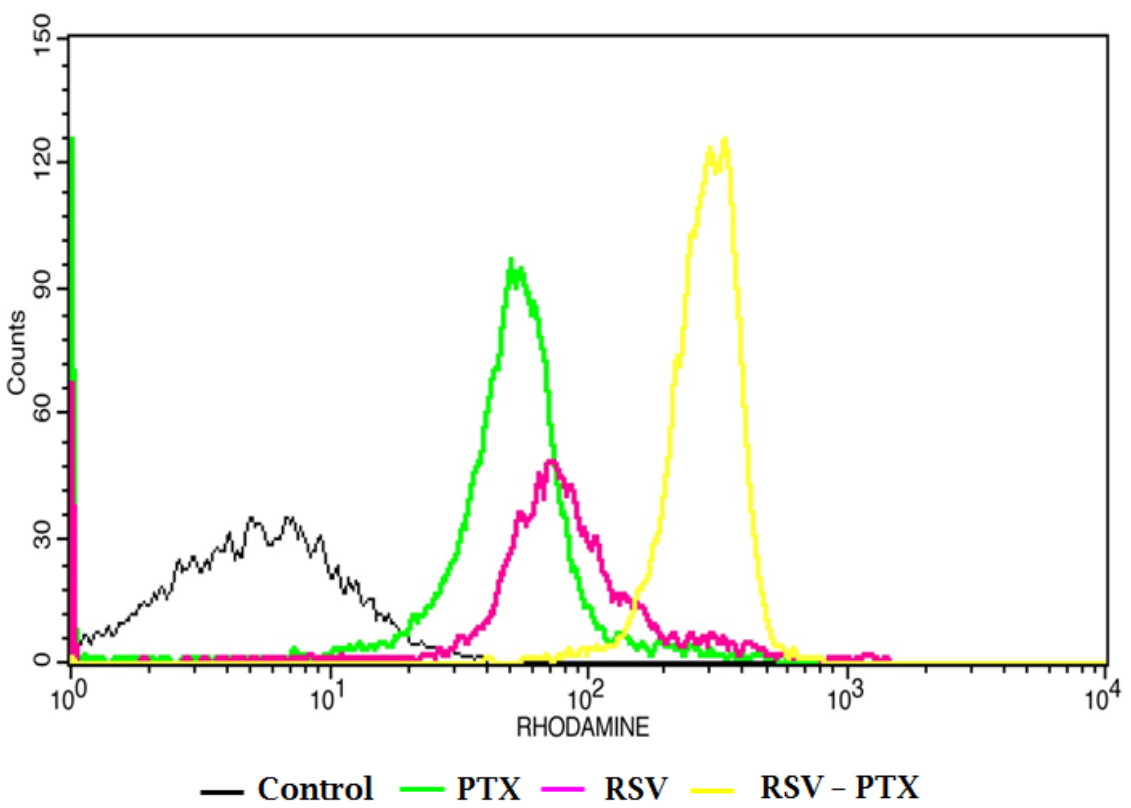

Figure 3: Accumulation of rhodamine 123 in NCl-H460 cells. Accumulation of rhodamine 123 in NCl-H460 cells in the absence or presence of RSV, PTX and RSV-PTX was analyzed by FACS flow cytometry.

(a) Western blot analysis

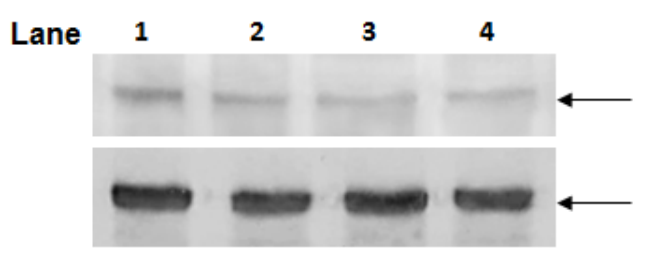

(b) Band intensity by densitometry

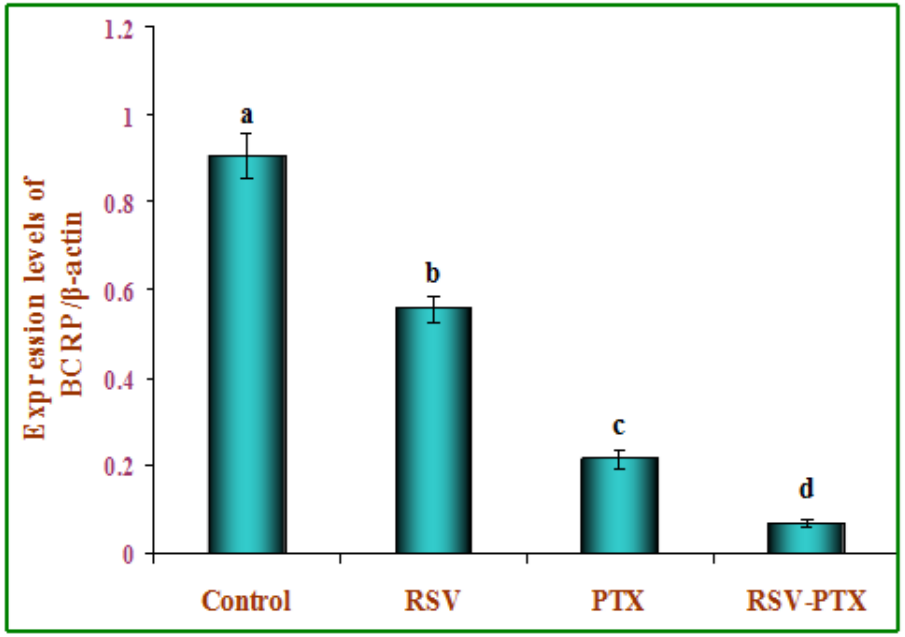

Figure 4: Western blot analysis of BCRP and $\beta$-actin expression in NCl-H460 cells. (a) Lane 1.Control 2.RSV 3.PTX and 4.RSV-PTX and band intensities were scanned by densitometer. Histogram of densitometry analysis represents the ratio of BCRP/ $\beta$-actin expression. (b) Effect of RSV and PTX on BCRP protein expression in $\mathrm{NCl}-\mathrm{H} 460$ cells. The graph represents the quantification results normalized to $\beta$-actin levels. Values not sharing a common marking (a, b, $\mathrm{c}$ ) differ significantly at $\mathrm{P}<0.05$ (DMRT)

expressions of $\mathrm{ABCB} 1 / \mathrm{MDR} 1, \mathrm{MDR} 3, \mathrm{LRP}, \mathrm{ABCC} 1, \mathrm{ABCC} 2$ and ABCC3 in NCI-H460 cells. The mRNA levels of these genes were down regulated under RSV alone or PTX alone treatment condition when compared to untreated control group. RSV-PTX combination resulted in a further down regulation of ABCB1/MDR1, MDR3, LRP, ABCC1, $\mathrm{ABCC} 2$ and $\mathrm{ABCC} 3$ genes in NCI-H460 cells.

\section{Cell cycle analysis}

Figure 6a and b show the effect of RSV and PTX on cell cycle modulation. Incubation of cells with RSV alone or PTX alone resulted in $43.91 \%$ and $49.95 \%$ increase of G2/M cell population in NCI-H460 cells. Incubation of cells with RSV-PTX combination showed a further enhancement of G2/M apoptotic cells (55.33\%) than all other treatment modalities.

\section{Discussion}

It has been reported that, lung cancer cells show significant resistance to PTX treatment [29]. Recently, there has been an increased interest in the use of natural compounds for the treatment of cancer patients, who constitutively express P-gp and are resistant to many chemotherapeutic agents. Some of these phytochemicals are nontoxic to animals. Previous studies have suggested that these compounds 
Citation: Karthikeyan S, Hoti SL, Prasad NR (2014) Resveratrol Modulates Expression of ABC Transporters in Non-Small Lung Cancer Cells: Molecular Docking and Gene Expression Studies. J Cancer Sci Ther 6: 497-504. doi:10.4172/1948-5956.1000314

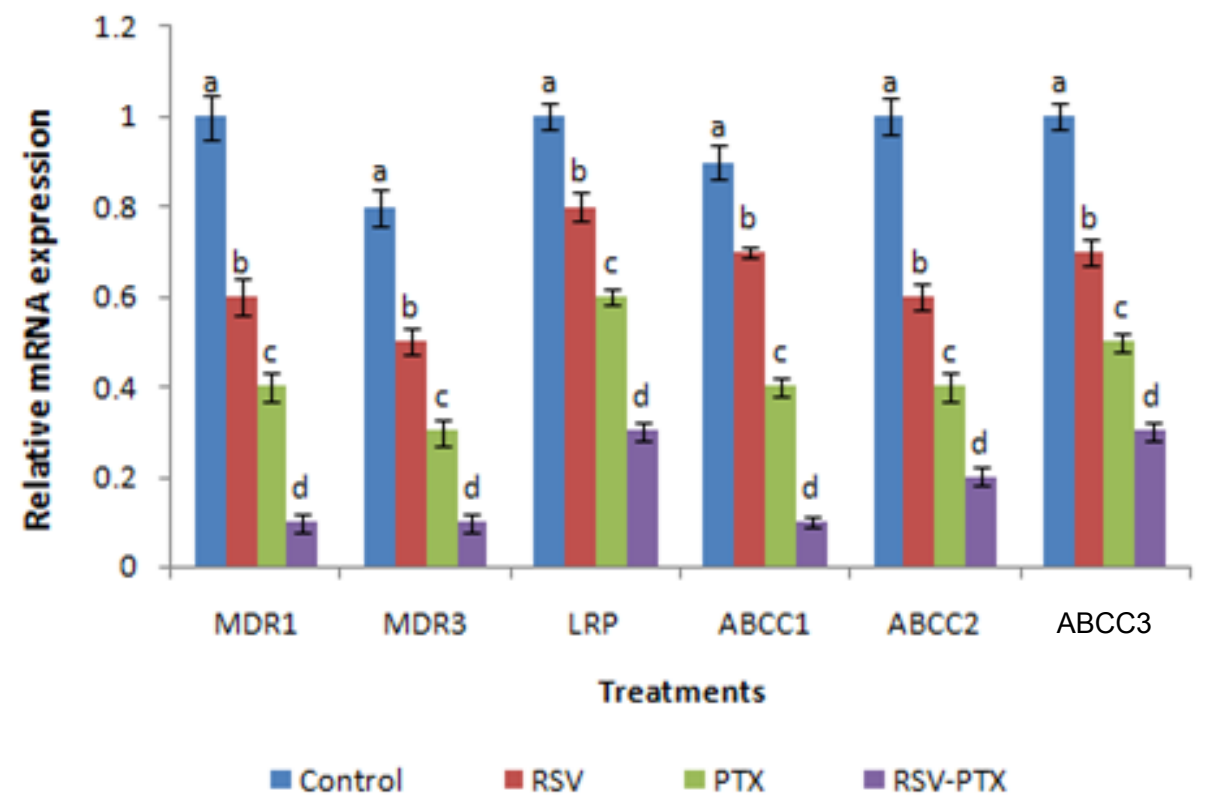

Figure 5: Effect of RSV-PTX on relative mRNA expression patterns of MDR1, MDR3, LRP ABCC1, ABCC2 and ABCC3 in NCI-H460 cells. The graph represents the quantification results normalized to $18 \mathrm{~S}$ rRNA. Values not sharing a common marking $(a, b, c)$ differ significantly at $P<0.05$ (DMRT).

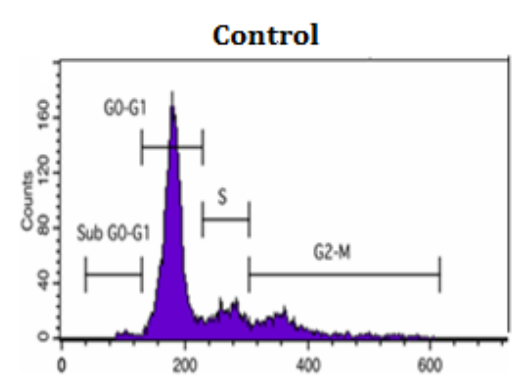

(a)
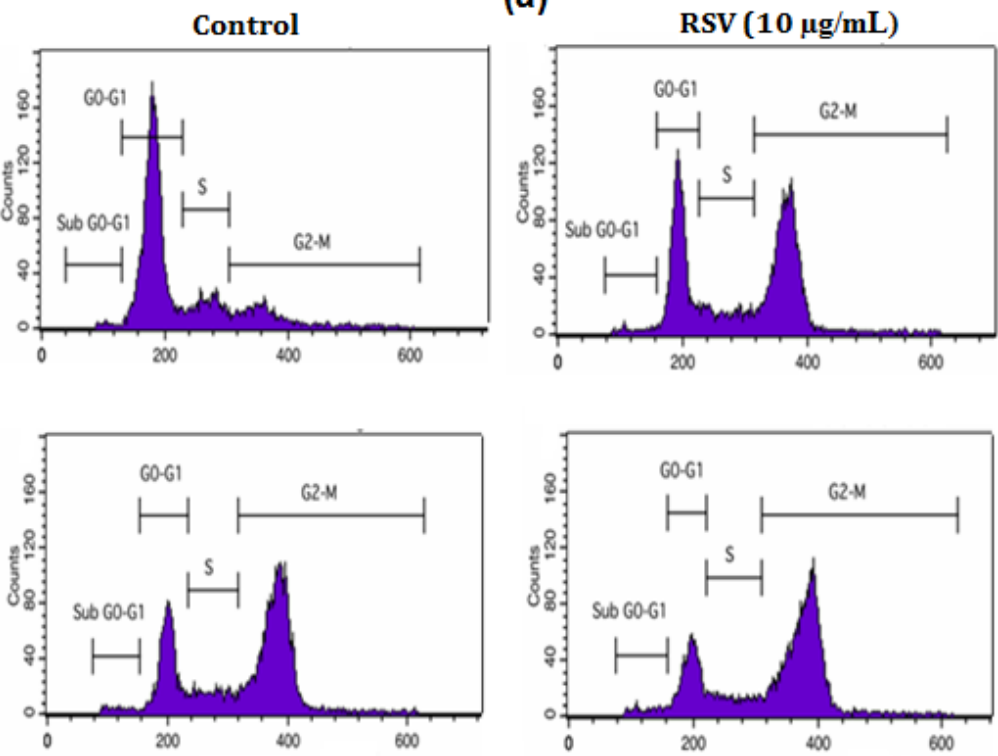

$\operatorname{PTX}(5 \mu \mathrm{g} / \mathrm{mL})$

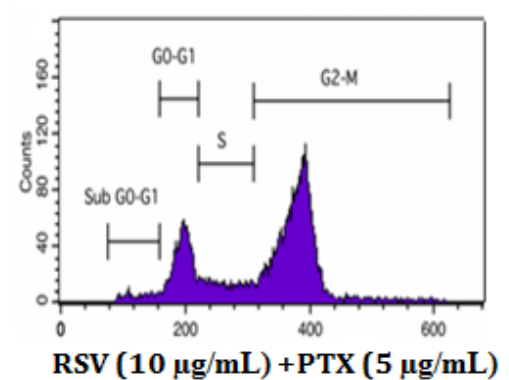

(b)

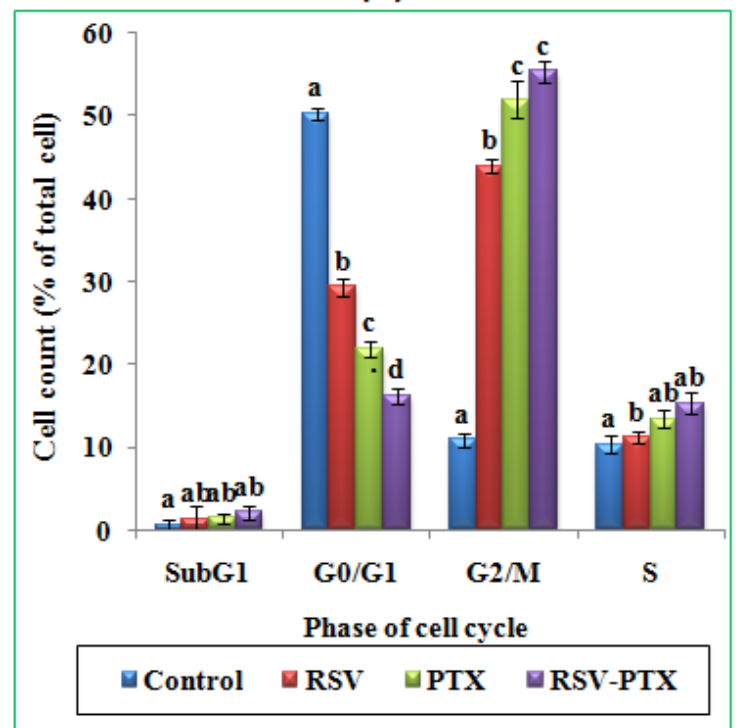

Figure 6: Effect of RSV-PTX on cell cycle and apoptosis (a) NCl-H460 cells were treated with RSV, PTX or RSV-PTX. RSV-PTX was able to increase the proportion of cells in G2/M as compared to RSV alone or PTX alone treated cells. (b) The bar graphs show the cell cycle distribution and the percentage of cells in each phase; these were obtained by calculation using the CellQuest software. Values not sharing a common marking $(a, b, c)$ differ significantly at $P<0.05$ (DMRT).

increase the accumulation and efficacy of chemotherapeutic agents through two potential mechanisms: (1) functional inhibition of P-gp mediated transport [32,33] and/or (2) a reduction of P-gp expression $[34,35]$. In this work, we investigated the chemosensitizing potential of RSV to PTX treatment to overcome MDR in NCI-H460 cells. The molecular interaction of RSV with P-gp was analyzed by Schrodinger software. The results were analyzed at the best orientation of the ligand RSV with P-gp and the docking images were documented for representation of ligand-receptor interaction. The values of docking score glide score and hydrogen bond score indicate RSV possesses significant binding affinity with P-gp. It has been also found that RSV forms hydrogen bonding with $\mathrm{Tyr}^{113}$ and $\mathrm{Tyr}^{949}$ residues which are located within the helical transmembrane domains of P-gp. These results indicate that RSV may have significant inhibitory effect on P-gp and thereby it may prevent the drug efflux mechanism mediated by this transporter. 
RSV $(10 \mu \mathrm{g} / \mathrm{mL})$ treatment $1 \mathrm{~h}$ before to PTX $(5 \mu \mathrm{g} / \mathrm{mL})$ exposure greatly inhibited the NCI-H460 cells proliferation. The present study also illustrated the superior anticancer effect of RSV-PTX combination than PTX alone or RSV alone treatment. Similar to our present findings, RSV inhibits cell growth and enhances the cytotoxicity of vincristine, paclitaxel and adriamycin in KBv200 cells [36]. Hence, it can be postulated that RSV could reverse multidrug resistance in NCI-H460 cells. Measurement of rhodamine 123 accumulation illustrates a direct measurement of the inhibition of P-gp function [36]. The cellular accumulation of rhodamine 123 was increased during RSV and PTX treatment. The increase in the accumulation of rhodamine 123 in multidrug-resistant cells after the addition of RSV indicates that this compound causes a modulation of resistance by inhibiting the pump function of P-gp. A pervious study has shown that RSV increased the intracellular concentrations of doxorubicin in myeloid leukemia cells by inhibiting membrane transport function [26]. Taken together, the present results indicate that RSV has inhibitory effects on P-gp function in NCI-H460 cells.

One of the major mechanisms of MDR is the enhanced ability of tumor cells to efflux drugs leading to a decrease in cellular drug accumulation below toxic levels. Active drug efflux is mediated by several members of the ABC superfamily of membrane transporters. The classical MDR is attributed to the elevated expression of P-gp, MRP1, and BCRP/ABCG2 [35]. Combined treatment of RSV-PTX has shown a significant decrease in the expression level of BCRP protein in NCI-H460 cells. Similar to our present findings, RSV increased the susceptibility of the doxorubicin-resistant cells to apoptotic cell death and downregulated the expression levels of MRP1 in acute myeloid leukemia-2/DX300 cells at both mRNA and protein levels [26]. RSVPTX treatment further significantly decreased the mRNA expression levels of ABCB1/MDR1, MDR3, LRP and ABCC2 in NCI-H460 cells. Overexpression of $\mathrm{P}$-gp is the most frequent event in causing multidrug resistance. It has been reported that RSV can inhibit the expression of MDR1/ P-gp and Bcl-2 [37]. Incubation of KBv200 cells with RSV caused an increase of vincristine-induced apoptosis by inhibiting Bcl-2 expression and downregulating P-gp [36]. Recent report showed that RSV inhibits genistein-induced MRP2 protein synthesis and its mRNA expression [38]. In this study, RSV sensitized NCI-H460 cells to PTX action by inhibiting MDR1/P-gp, LRP, MRP2 and ABCC2 expression. Therefore, downregulation of $\mathrm{ABC}$ transporters expressions may be involved in the chemosensitizing effect of RSV in non-small cell lung cancer cells.

It has been reported that PTX exerts cytotoxicity by inhibiting tubulin polymerization resulting in unstable microtubules which interferes with mitotic spindle function and ultimately arrests cells in the G2-M phase of mitosis [39]. Drug-induced G2/M arrest is associated with double-strand DNA breakage and extensive chromosome damage [40]. Therefore, the increased G2/M phase arrest indicates cell division inhibition and cell growth restrain [41]. In this study, RSV-PTX combination was investigated to understand whether this combination could induce the cell cycle arrest in NCI-H460 cells. When NCI-H460 cells were treated with RSV-PTX, a reduction in the fraction of cell in the G0/G1 and S phase, and a higher accumulation of cells in the G2/M phase were found. These data suggest the boosted cytotoxicity observed for RSV-PTX combination and this might be as a result of enhanced intracellular PTX concentration.

In summary, we have investigated the chemosensitizing potential of RSV to enhance the antitumor efficacy of PTX in NCI-H460 cells. The molecular interactions of RSV possess significant binding affinity with helical transmembrane region of P-gp. It was found that RSV with
PTX had superior antiproliferation activity against NCI-H460 cells compared with PTX alone. RSV treatment is able to increase rhodamine 123 accumulations in NCI-H460 cells which suggest that this compound may act by inhibiting membrane transport activity. RSVPTX treatment further significantly decreased the mRNA expression levels of ABCB1/MDR1, MDR3, LRP and ABCC2 in NCI-H460 cells. Further the protein level of BCRP was down-regulated during RSV pretreatment. Furthermore, an enhanced anticancer efficacy of RSVPTX treatment was observed which might be associated with PTXinduced cell arrest at the G2/M phase. Therefore, the present result illustrates chemosensitizing potential of RSV in a NCI-H460 cells which may be due to its membrane transport function inhibition and down regulation of MDR associated $\mathrm{ABC}$ transporters. Moreover, the possibility of numerous substitute activities for $\mathrm{ABC}$ transporters also exists, thus warranting further investigations on the identification of MDR modulators from natural sources, for treatment as well as long term goal of development of effective chemomodifier to be applicable in health care and clinical oncology.

\section{Acknowledgements}

This work was supported by a research grant from the Indian Council of Medical Research (ICMR), Ministry of Health and Family Welfare, Government of India, New Delhi, is gratefully acknowledged.

\section{References}

1. Jemal A, Thun MJ, Ries LA, Howe HL, Weir HK, et al. (2008) Annual report to the nation on the status of cancer, 1975-2005, featuring trends in lung cancer, tobacco use, and tobacco control. J Natl Cancer Inst 100: 1672-1694.

2. Kitazono M, Sumizawa T, Takebayashi Y, Chen ZS, Furukawa T, et al. (1999) Multidrug resistance and the lung resistance-related protein in human colon carcinoma SW-620 cells. J Natl Cancer Inst 91: 1647-1653.

3. Gottesman MM, Ambudkar SV (2001) Overview: ABC transporters and human disease. J Bioenerg Biomembr 33: 453-458.

4. Trussardi A, Poitevin G, Gorisse MC, Faroux MJ, Bobichon H, et al. (1998) Sequential overexpression of LRP and MRP but not P-gp 170 in VP16-selected A549 adenocarcinoma cells. Int J Oncol 13: 543-548.

5. Berger W, Setinek U, Hollaus P, Zidek T, Steiner E, et al. (2005) Multidrug resistance markers P-glycoprotein, multidrug resistance protein , and lung resistance protein in non-small cell lung cancer: prognostic implications. $J$ Cancer Res Clin Oncol 131: 355-363.

6. Meschini S, Marra M, Calcabrini A, Monti E, Gariboldi M, et al. (2002) Role of the lung resistance-related protein (LRP) in the drug sensitivity of cultured tumor cells. Toxicol In Vitro 16: 389-398.

7. Donnenberg VS, Donnenberg AD (2005) Multiple drug resistance in cancer revisited: the cancer stem cell hypothesis. J Clin Pharmacol 45: 872-877.

8. Sparreboom A, Danesi R, Ando Y, Chan J, Figg WD (2003) Pharmacogenomics of $A B C$ transporters and its role in cancer chemotherapy. Drug Resist Updat 6: 71-84.

9. Leslie EM, Mao Q, Oleschuk CJ, Deeley RG, Cole SP (2001) Modulation of multidrug resistance protein 1 (MRP1/ABCC1) transport and atpase activities by interaction with dietary flavonoids. Mol Pharmacol 59: 1171-1180.

10. Zhang S, Yang X, Morris ME (2004) Flavonoids are inhibitors of breast cancer resistance protein (ABCG2)-mediated transport. Mol Pharmacol 65: 12081216.

11. Wu CP, Calcagno AM, Hladky SB, Ambudkar SV, Barrand MA (2005) Modulatory effects of plant phenols on human multidrug-resistance proteins, 4 and 5 (ABCC, 4 and 5). FEBS J 272: 4725-4740.

12. Morris ME, Zhang S (2006) Flavonoid-drug interactions: effects of flavonoids on ABC transporters. Life Sci 78: 2116-2130.

13. Cermak R, Wolffram $S$ (2006) The potential of flavonoids to influence drug metabolism and pharmacokinetics by local gastrointestinal mechanisms. Curr Drug Metab 7: 729-744.

14. Brand W, Schutte ME, Williamson G, van Zanden JJ, Cnubben NH, et al. (2006) 
Citation: Karthikeyan S, Hoti SL, Prasad NR (2014) Resveratrol Modulates Expression of ABC Transporters in Non-Small Lung Cancer Cells: Molecular Docking and Gene Expression Studies. J Cancer Sci Ther 6: 497-504. doi:10.4172/1948-5956.1000314

Flavonoid-mediated inhibition of intestinal $A B C$ transporters may affect the oral bioavailability of drugs, food-borne toxic compounds and bioactive ingredients. Biomed Pharmacother 60: 508-519.

15. Piao Y, Shin SC, Choi JS (2008) Effects of oral kaempferol on the pharmacokinetics of tamoxifen and one of its metabolites, 4-hydroxytamoxifen, after oral administration of tamoxifen to rats. Biopharm Drug Dispos 29: 245 249.

16. Kawada N, Seki S, Inoue M, Kuroki T (1998) Effect of antioxidants, resveratrol, quercetin, and $\mathrm{N}$-acetylcysteine, on the functions of cultured rat hepatic stellate cells and Kupffer cells. Hepatology 27: 1265-1274.

17. Donnelly LE, Newton R, Kennedy GE, Fenwick PS, Leung RH, et al. (2004) Anti-inflammatory effects of resveratrol in lung epithelial cells: molecular mechanisms. Am J Physiol Lung Cell Mol Physiol 287: L774-783.

18. Manna SK, Mukhopadhyay A, Aggarwal BB (2000) Resveratrol suppresses TNF-induced activation of nuclear transcription factors NF-kappa B, activator protein-, and apoptosis: potential role of reactive oxygen intermediates and lipid peroxidation. J Immunol 164: 6509-6519.

19. Gusman J, Malonne H, Atassi G (2001) A reappraisal of the potentia chemopreventive and chemotherapeutic properties of resveratrol. Carcinogenesis 22: 1111-1117.

20. Jang M, Cai L, Udeani GO, Slowing KV, Thomas CF, et al. (1997) Cance chemopreventive activity of resveratrol, a natural product derived from grapes. Pezzuto JM Science 275: 218-220.

21. Zhao J, Wang J, Chen Y, Agarwal R (1999) Anti-tumor-promoting activity of a polyphenolic fraction isolated from grape seeds in the mouse skin two-stage initiation-promotion protocol and identification of procyanidin B5-3'-gallate as the most effective antioxidant constituent. Carcinogenesis 20: 1737-1745.

22. Estrov Z, Shishodia S, Faderl S, Harris D, Van Q, et al. (2003) Resveratro blocks interleukin-1beta-induced activation of the nuclear transcription factor NF-kappaB, inhibits proliferation, causes S-phase arrest, and induces apoptosis of acute myeloid leukemia cells. Blood 102: 987-995.

23. Ulrich S, Wolter F, Stein JM (2005) Molecular mechanisms of the chemopreventive effects of resveratrol and its analogs in carcinogenesis. Mol Nutr Food Res 49: 452-461.

24. Aggarwal BB, Shishodia S (2006) Molecular targets of dietary agents for prevention and therapy of cancer. Biochem Pharmacol 71: 1397-1421.

25. Liu H, Liu Q, Zhang H (2004) Effect of resveratrol combined with chemotherapeutic agent on mouse hepatoma carcinoma cell line in vivo and in vitro. Chin J Exp Surgery 21: 230.

26. Kweon SH, Song JH, Kim TS (2010) Resveratrol-mediated reversal of doxorubicin resistance in acute myeloid leukemia cells via downregulation of MRP1 expression. Biochem Biophys Res Commun 395: 104-110.

27. Bhalla KN (2003) Microtubule-targeted anticancer agents and apoptosis. Oncogene 22: 9075-9086.
28. Vikhanskaya F, Vignati S, Beccaglia P, Ottoboni C, Russo P, et al. (1998) Inactivation of p53 in a human ovarian cancer cell line increases the sensitivity to paclitaxel by inducing G2/M arrest and apoptosis. Exp Cell Res 241: 96-101.

29. Zhang W, Shi Y, Chen Y, Yu S, Hao J, et al. (2010) Enhanced antitumor efficacy by paclitaxel-loaded pluronic P123/F127 mixed micelles against nonsmall cell lung cancer based on passive tumor targeting and modulation of drug resistance. Eur J Pharm Biopharm 75: 341-353.

30. Mosmann T (1983) Rapid colorimetric assay for cellular growth and survival: application to proliferation and cytotoxicity assays. J Immunol Methods 65: 5563.

31. Chaudhary PM, Roninson IB (1991) Expression and activity of P-glycoprotein a multidrug efflux pump, in human hematopoietic stem cells. Cell 66: 85-94.

32. Ji BS, He L, Liu GQ (2005) Reversal of P-glycoprotein-mediated multidrug resistance by $\mathrm{CJX}$, an amlodipine derivative, in doxorubicin-resistant human myelogenous leukemia (K562/DOX) cells. Life Sci 77: 2221-2232.

33. Limtrakul P, Khantamat O, Pintha K (2004) Inhibition of P-glycoprotein activity and reversal of cancer multidrug resistance by Memordica charantia extract. Cancer Chemother Pharmacol 54: 525-530.

34. Anuchapreeda S, Leechanachai P, Smith MM, Ambudkar SV, Limtrakul PN (2002) Modulation of P-glycoprotein expression and function by curcumin in multidrug-resistant human KB cells. Biochem Pharmacol 64: 573-582.

35. Tang XQ, Bi H, Feng JQ, Cao JG (2005) Effect of curcumin on multidrug resistance in resistant human gastric carcinoma cell line SGC7901/VCR. Acta Pharmacol Sin 26: 1009-1016.

36. Quan F, Pan C, Ma Q, Zhang S, Yan L (2008) Reversal effect of resveratrol on multidrug resistance in KBv200 cell line. Biomed Pharmacother 62: 622-629.

37. Jeong SH, Jo WS, Song S, Suh H, Seol SY, et al. (2009) A novel resveratrol derivative, HS1793, overcomes the resistance conferred by $\mathrm{Bcl}-2$ in human leukemic U937 cells. Biochem Pharmacol 77: 1337-1347.

38. Kim JH, Chen C, Tony Kong AN (2011) Resveratrol inhibits genistein-induced multi-drug resistance protein 2 (MRP2) expression in HepG2 cells. Arch Biochem Biophys 512: 160-166

39. Jordan MA, Toso RJ, Thrower D, Wilson L (1993) Mechanism of mitotic block and inhibition of cell proliferation by taxol at low concentrations. Proc Natl Acad Sci U S A 90: 9552-9556.

40. Ahmed F, Pakunlu RI, Brannan A, Bates F, Minko T, et al. (2006) Biodegradable polymersomes loaded with both paclitaxel and doxorubicin permeate and shrink tumors, inducing apoptosis in proportion to accumulated drug. J Control Release 116: 150-158.

41. Ng SSW, Tsao MS, Chow S, Hedley DW (2000) Inhibition of phosphatidylinositide 3-kinase enhances gemcitabine-induced apoptosis in human pancreatic cancer cells. Cancer Res 60: 5451-5455. 